\title{
DETERMINING CUSTOMER EXPECTATIONS IN REAL ESTATE: A POTENTIAL MARKET FOR ISTANBUL/ TURKEY
}

\author{
Irem ERDOĞMUŞ \\ Emine ÇOBANOĞLU \\ Marmara University, Turkey
}

\section{ABSTRACT}

The purpose of the study is to present a segmentation of the potential real estate customers in Istanbul with regard to their evaluation of real estate amenities and profiling them in order to prepare strategic guidelines for the international and national construction companies that plan to invest in real estate in Istanbul. The study was conducted with a sample of 183 people who intend to purchase real estate in the next three years. Data collection was carried through the administration of a structured questionnaire which investigated the evaluation of real estate alternatives in terms of importance given in real estate purchase decisions, and which methods were utilized for real estate information collection. The Analysis of the Housing Amenities Scale resulted in seven factors; luxury life style, individual living area, ocation related, modern life style, open area related, payment related and modernity. The next level of analysis involved cluster analyzing the factor scores to group individual respondents in order to segment the respondents based on their answers to the importance of real estate amenities. The optimal solution produced three clusters: contendeds, dolce vitas and city dwellers. This is a pioneering study for profiling potential real estate customers in Turkey and segmenting the market according to required amenities. In the near future, more severe competition is expected, what makes marketing and customer orientation a neccessity. Turkish marketers must be on track of the changing customer expectations, and design strategies to fulfill those requirments.

Key Words: İstanbul Real Estate Market, market segmentation strategy, real estate amenities, real estate buyer behavior, cluster analysis

\section{INTRODUCTION}

Turkish Real Estate Sector is going through major changes that affect the demand and supply structure of the sector. Thus, in such periods of change, be it a "property boom" or on the other extreme an economical crisis, project development and management becomes an even more important topic of interest (Wernecke, Rottke, and Holzmann 2004), as the real estate market becomes more competitive, with the customer becoming more selective, and the firms striving to create better solutions and strategies. Prior to 1999, although Turkey was known to be in the earthquake zone, consumer consciousness about the issue was rather low. After the earthquake, consumers' consciousness related to construction and quality standards has changed, which created demand for new projects. Moreover, the increase in population especially in the urban areas, the city renewal projects that change slums to regular homes, the fact that $60 \%$ of the existing homes do not fit with the present construction quality requirements and regulations, and the need for renewal of old homes increase the demand for new construction projects (İçli 2008). The mortgage law introduced in 2007, have also made real estate more affordable for the average Turkish family. Meanwhile, the macro environmental conditions, especially economic factors like inflation rate, loan rates and the purchase power of households continously affect the demand structure either positively and negatively (İçli 2008). Currently, the house ownership in Turkey is around 60 percent, which shows that there is still unfulfilled demand, creating market opportunities (Gayrimenkul Yatırım Ortaklığı Derneği/ The Association of Real Estate Investment Companies 2006).

On the supply side, the increase in demand has resulted 
in increase in profitability for construction companies and increase in the number of projects as well (Konutta fiyatlar TOKİ seviyesinde/ The house prices are at TOKİ levels 2008). As there are more alternatives for purchase in the market, it is essential for the construction companies to be market oriented and to design the projects according to the requirements of the customer for getting competitive advantage. In order to be more effective, the companies should be aware of the current and potential customers' demands, attitudes, and preferences in real estate. It is true that price, quality and quantity of amenities go hand in hand. However, there might be different market segments who would value these characteristics differently and the successful marketers should design their strategies to equate demand and supply in each segment (Anglin 1997).

For a construction company to succeed, segmenting the market and determining the product requirements of each segment is very important (İcli 2008). Research has shown that market segments may be defined in terms of differences in the relative importance given to each amenity, and the segmentation criteria do not necessarily correspond to simple demographic characteristics (Nelson and Rabianski 1988). Right criteria for segmentation are especially required for Turkey and İstanbul where there is high competition due to increasing numbers of contruction projects to satisfy demand. For these projects to be successful, it is important that the right segments are targeted and the right amenities are designed with the right marketing mix (Pehlivanl1 2007). Therefore, the objective of this study is to present real estate segmentation based on the Istanbul consumers' evaluation of amenities in real estate and profile these segments in terms of their preferences and characteristics. Additionally, the sources of information, decision making process, and implementation strategies to reach these segments are other aims to be considered. The implications of this research are to prepare strategic guidelines for the construction companies to design and manage their projects and marketing activities according to the demand and consumer behavior of different market segments.

Turkey and İstanbul were selected as the context of this study because real estate in İstanbul promises opportunities for both foreign and domestic investors (Emerging Trends in Real Estate Europe 2007). Turkish real estate market has attracted foreign investment from all around the world with Europe leading the way. Unsurprisingly, many national and international retail chains such as Turyap, Coldwell Banker, Remax, Reha Medin, Century 21, Realty
World, Eskidji are opening franchise offices all around the country at a fascinating rate. Only in Istanbul, there are 415 branded franchise offices as of 2007, let alone the independent retail offices (Cingi, 2007). Six executives from the Turkish real estate sector had already been invited and attented the "Global Real Estate Institute Conference- Europe 2006" to discuss the growth, developments, and the opportunities in the Turkish real estate sector, especially in İstanbul (Türk Emlakçılarının Paris Çıkarması/ The Parisian Landing of the Turkish Real Estate Agents 2007). Most real estate consumers felt the need to have a house in İstanbul because they believed that at least once in their lives, they had to live in İstanbul for a while for various reasons such as education, work, or holiday (Özdemir 2008). In İstanbul, it is forcasted that till 2015, every year there will be need for 250.000 new houses. İstanbul is also considered as the most promising market in real estate in terms of income and opportunities in 2007 by Urban Land Institute and Pricewaterhouse Coopers (Istanbul'un taşı toprağ altın/ Land and stone in Istanbul is golden http://www.kobifinans.com.tr/tr/sektor/0117/18461/5). Thus, a keener look into the Turkish and Istanbul real estate market and determination of different consumer segments and decision making process with a focus on İstanbul is timely and warranted.

\section{CONSUMER REAL ESTATE DECISION MAKING}

Neoclasical economics assume that individuals make rational economic decisions to maximize their utility. Real estate buying is one of the complex buying processes where the consumer is highly involved in the purchase, makes such purchases infrequently, also the purchase is highly self-expressive, and expensive (Kotler and Armstrong 2008); moreover, it is characterized by incomplete information, costly search and varying expectations (Quan and Quigley 1991). Complex buying process involves all of the steps of consumer decision making; problem recognition, information search, evaluation of alternatives, purchase and post purchase (Levy and Lee 2002). In order to maximize utility and to find the "right" product in the process, consumer is willing to spend time and effort in each of these steps.

For most households, buying a house is one of the most significant but also infrequent transaction. Problem recognition is the initiation stage of the process. There might be different reasons of buying at this stage. People might consider buying a real estate for living and consumption, or for investment (Elder and Zumpano 1991). The decision might be 
triggered by several factors listed below (Loudan ve Bitta 1988; Rosenauer ve Myfield 2007):

1. Their house might have grown old,

2. They might have grown bored of their house,

3. New members might have been added to the households,

4. Promotions might have attracted their interest,

5. A new work, wanting to be close to the family, wanting to change their social circle, search for novelty might have triggered them.

Following the problem recognition, information search starts. Real estate market can be characterised by having incomplete information. Actually the product is nonhomogenous and information is costly to obtain, which makes the role of the intermediaries very critical (Baryla and Zumpano 1995). The buyer cannot know without searching which property offers the best match (Ford, Rutherford, and Yavaş, 2005). Real estate agencies play an important role in the information search process since they had already compiled most of the information necessary for customers. Having an agent who knows the tastes of the buyers very well is a perfect substitute for the customer's own efforts (Day and Nourse 1991, Benjamin, Jud, and Sirmans, 2000). Real estate brokers help buyers gain information, and provide marketing and financial expertise (Johnson and Hamilton 1996). The newspapers may also provide a useful source since a customer who carefully reads newspapers can more easily locate his own house and buy in less time rather than depend on a real estate agent (Anglin 1997). There is the increasing use of the Internet for searching real estate information. It is much cheaper and easier for those who are technologically ready to use the Internet. There is high quality and quantity of information available. Buyers that search real estate information from the Internet can search for more properties, have virtual tours of the home interiors, be better informed, and enjoy a better expected match (Benjamin, Jud, and Sirmans, 2000; Ford, Rutherford, and Yavaş, 2005). However, search on the Web takes longer time (Ford, Rutherford, and Yavaş, 2005) minimizing the information search cost.

The evaluation of alternatives and selection of real estate is a complex decision which involves a lot of comparisons on amenities of different alternatives. Potential buyers in housing/real estate markets have heterogeneous preferences over property characteristics. Properties differ from each other with respect to certain features. The matching game in housing markets involves more than simply pairing a buyer with a seller. There also needs to be a match between the buyer's preference and the characteristics of the construction project (Ford, Rutherford, Yavas, 2005).

Most of the amenities of different alternatives are physical characteristics such as amount of square footage, location, closeness to work, surrounding neighboorhood, neighbourhood externalities, expenses, architectural design, age of the building, parking place, newness (Smith, Garbarino, and Martini 1992, Anglin 1997). Building characteristics are important criteria to be considered, however, research has proved that selection of location is equally important (Anglin 1997). Research suggests that consumer characteristics like psychographics as well as gender, family lifecycle, income, and prior experience (Anglin 1997, Levy and Lee 2002, Elder and Zumpano 1991) influence the amenities searched for and evaluation process among alternatives.

Women and men differ in what they search for in a real estate. Women are more interested in issues related to how the family will live in the house, whereas the men are interested in practical issues such as resale value, and/or materials used in the construction (Levy and Lee 2002).

Family life cycle refers to the changes that occur in family structure as the family progresses over time (Levy and Lee 2002). In simplistic terms, there might be singles and marrieds. However, marrieds can further be classified as those without children, those with small families, those with large families. Finally, with the rising divorce rates, there is a newer family structure called single parent families (Lawson et al. 1996). Research has shown that especially children influence family decision making. Their influence is through creation of derived demand effect on their parents. Parents take into consideration the number of children and their needs and wants when deciding on the size of the house, number of bedrooms, the location, and the surrounding environment (Levy and Lee 2002).

Income of the customers is also important in determining what kind of amenities are searched for, and which can be afforded. The price of the property has an equal value with that of the amenities in the evaluation of alternatives. Research shows that higherpriced houses have more amenities (Anglin 1997). Research has also shown that upper income customers prefer housing outside the city center in suburban locations, while low income families reside in the cities, close to work. (Elder and Zumpano 1991).

Prior experienced buyers of real estate enjoy the advantage of having gone through the process and 
their expectations are more accurate for the second or third times. Lack of prior information and experience in the issue makes the customers less accurate of housing expectations (Anglin 1997).

The final decision, purchasing a real estate, resides on the leader of the family. Women or men can decide independently, as well as both can decide jointly. Depending on the democratic structure of the family and the main income earner, the role of the family members differ as main decision maker. Children in the beginning of their adolescence have a direct influence on the final say since they are the ones who are mostly interested in their own space in the house, the location, and the neighbourhood that the house is located at (Levy and Lee 2002).

Once the consumer buys the house, the post purchase process starts. In the post purchase stage, one of the important considerations is the long term value of the house (Shim, Lee and Kim 2008). Another improtant issue is the satisfaction from the purchase. Depending on the expectations of the customer, the fulfillment of the expectations will result in satisfaction and also a learning process. As the consumer feels that the value of the investment increased and find satisfaction in the purchase, trust in the construction company and the broker is established resulting in longer relationships and less inclination to sell the house (Shim et all 2008). The customer will be inclined to purchase from the same vendor when the need arise.

\section{RESEARCH METHODOLOGY}

The specific research question addressed in this study was whether there were different real estate customer segments in Istanbul based on evaluation of a list of real estate amenities. The focus was on the evaluation of alternatives phase of the consumer decision making. Related to this question, the study also investigated the information search process of the real estate consumer decision making.

The research was conducted in Istanbul with a sample of 183 people who intend to purchase real estate in the next three years. Data collection was carried through the administration of a structured questionnaire. The questionnaire investigated reason of buying, the evaluation of real estate alternatives in terms of importance given in real estate purchase decisions, and which methods were utilized for information collection. The amenities included in the questionnaire were drawn from literature, but in-depth, face-to-face interviews with ten real estate consumers who had recently bought a house within a six month period were carried on to add and drop certain amenities to fit the local context. An importance scale was utilized to measure the consumers' evaluation of amenities anchored between $1=$ not important at all to $4=$ very important. The scale proved reliable with a Cronbach's alpha coefficient of 0.86 .

\section{RESEARCH FINDINGS}

To understand the overall evaluation of the respondents and which amenities were ranked more important than the others, the first thing was to mean rank the amenities as presented in Table 1 . The results show that resistance to earthquake was the most important amenity $(\mu=3.7971)$ followed by price premiums $(\mu=3.5485)$ and reasonable prices $(\mu=3.4854)$, and a trustable construction company $(\mu=3.4732)$. The least important amenities, on the other hand, were sauna (mean value $=1.8098)$, house type $(\mu=1.9855)$, and multistories $(\mu=2.0000)$.

The amenities were then factor analyzed (using principle components, varimax rotation) to reduce the total items to a more managable number and detect patterns in data. The analysis yielded a seven-factor solution that explained approximately $61 \%$ of the variance. The factors of real estate evaluation are named as modern lifestyle, payment conditions, individual living area, location-related, modernity, open area related, and luxury life style. The corresponding factors and elements under the factors are presented in Table 2.

The next level of analysis involved cluster analyzing the factor scores to group individual respondents; in essence, to segment our respondents based on their answers to the importance of real estate amenities. The optimal solution produced three clusters. The initial seeds of the clusters on the factors are presented in Table 3.

Based on the factors, we can characterize the clusters as follows: contenteds (C1), dolce vita (C2), and city dwellers (C3). To get a better picture of the clusters, reason of buying, and basic demographic characteristics were further examined and shown in Table 4. The overall results provide interesting profiles for İstanbul real estate consumers.

The contendeds consider the luxury lifestyle $(\mu=1.55)$, open area $(\mu=1.87)$ and modernity $(\mu=2.26)$ amenities the least in their real estate decisions. The location $(\mu=2.98)$, house related $(\mu=2.86)$, and security amenities $(\mu=2.99)$ are moderately considered whereas payment $(\mu=3.10)$ is the most important factor determining their real estate decision. Most of them $(47.8 \%)$ buy real estate for living whereas some 
Table 1 Mean Ranking of Evaluation of Housing Amenities

\begin{tabular}{|c|c|c|c|c|}
\hline & Mean & $\begin{array}{l}\text { Standard } \\
\text { Deviation }\end{array}$ & $\begin{array}{l}\text { Mean } \\
\text { Rank }\end{array}$ & $\begin{array}{l}\text { Friedman Test } \\
\text { Result }\end{array}$ \\
\hline Resistance to earthquake & 3.7971 & 0.5373 & 29,29 & $\mathrm{~N}: 165$ \\
\hline Price Premium in the future & 3.5485 & 0.6735 & 26,55 & Chi- \\
\hline \multicolumn{5}{|l|}{ Square: 1853,248} \\
\hline Reasonable price & 3.4854 & 0.6531 & 25,89 & \multirow{34}{*}{$\begin{array}{l}\text { Df: } 35 \\
\text { P value: } 0.000\end{array}$} \\
\hline Built by a trustable construction Company & 3.4732 & 0.7955 & 26,88 & \\
\hline Gets sunshine & 3.4223 & 0.6486 & 24,91 & \\
\hline Heat protection & 3.3854 & 0.6808 & 24,81 & \\
\hline With security & 3.3039 & 0.8038 & 23,95 & \\
\hline With balcony & 3.2390 & 0.6762 & 23,18 & \\
\hline Individual heating system & 3.2319 & 0.7532 & 22,57 & \\
\hline With parking space & 3.1990 & 0.8288 & 22,66 & \\
\hline $\begin{array}{l}\text { Neighbors from similiar social } \\
\text { background as mine }\end{array}$ & 3.1317 & 08559 & 21,46 & \\
\hline $\begin{array}{l}\text { Finishing details of the kitchen and } \\
\text { bathroom according to my expectations }\end{array}$ & 3.1063 & 0.7493 & 21,48 & \\
\hline Fit for mortgage & 3.0878 & 0.8977 & 21,20 & \\
\hline In a neighborhood that I like & 3.0485 & 0.8709 & 20,57 & \\
\hline In the city center & 3.0146 & 0.9185 & 20,56 & \\
\hline Newly built & 2.9854 & 0.8487 & 20,34 & \\
\hline $\begin{array}{l}\text { Price that is to be paid in installment basis } \\
\text { to the construction Company }\end{array}$ & 2.9709 & 0.9571 & 19,84 & \\
\hline Close to my Office & 2.9118 & 1.0034 & 19,22 & \\
\hline Big physical space & 2.8647 & 0.7575 & 18,78 & \\
\hline With view & 2.8252 & 0.8602 & 18,35 & \\
\hline In a condominium complex & 2.7961 & 0.8306 & 18,05 & \\
\hline With a garden & 2.7488 & 0.9162 & 17,98 & \\
\hline Maintanence performed by the & 2.5894 & 0.9555 & 16,19 & \\
\hline Social activities (like restaurants) & 2.4927 & 0.9000 & 14,95 & \\
\hline Open sports fields & 2.4396 & 0.9216 & 14,43 & \\
\hline Technology friendly & 2.4341 & 0.9659 & 14,45 & \\
\hline Play ground for children & 2.4098 & 0.9989 & 14,82 & \\
\hline Pathway for walking & 2.3835 & 0.9388 & 14,14 & \\
\hline Built in white goods & 2.3235 & 0.9640 & 13,56 & \\
\hline Swimming pool & 2.2705 & 0.9824 & 12,73 & \\
\hline Outside the city center & 2.1546 & 0.9800 & 12,03 & \\
\hline Fitness center & 2.1359 & 0.9427 & 11,12 & \\
\hline Heating system in the floor & 2.0874 & 0.8217 & 10,41 & \\
\hline Multi-stories & 2.0000 & 0.7483 & 10,37 & \\
\hline House & 1.9855 & 1.1720 & 9,90 & \\
\hline Sauna & 1.8098 & 08447 & 8,37 & \\
\hline
\end{tabular}


Table 2 Factor Analysis Results for the Housing Amenities Scale

\begin{tabular}{|c|c|c|c|c|}
\hline & $\begin{array}{r}\text { Factor } \\
\text { Loading }\end{array}$ & $\begin{array}{r}\text { Variance } \\
\text { Explained }\end{array}$ & $\begin{array}{r}\text { Cronbach } \\
\text { Alpha } \\
\end{array}$ & $\begin{array}{l}\text { No. of } \\
\text { Items }\end{array}$ \\
\hline Factor 1: Luxury life style & & 22.953 & 0.85 & 6 \\
\hline Fitness center & 0.810 & & & \\
\hline Swimming pool & 0.785 & & & \\
\hline Open sports fields & 0.773 & & & \\
\hline Pathway for walking & 0.643 & & & \\
\hline Sauna & 0.641 & & & \\
\hline House & 0.538 & & & \\
\hline Factor 2: Individual living area & & 11.144 & 0.69 & 5 \\
\hline With balcony & 0.757 & & & \\
\hline \multicolumn{5}{|l|}{ Finishing details of the kitchen and bathroom } \\
\hline according to my expectations & 0.617 & & & \\
\hline With view & 0.600 & & & \\
\hline Neighbors from similiar social background as mine & 0.573 & & & \\
\hline Gets sunshine & 0.565 & & & \\
\hline Factor 3: Location related & & 7.361 & 0.63 & 3 \\
\hline Close to my Office & 0.818 & & & \\
\hline In the city center & 0.668 & & & \\
\hline In a neighborhood that I like & 0.629 & & & \\
\hline Factor 4: Modern life style & & 5.735 & 0.66 & 4 \\
\hline With security & 0.654 & & & \\
\hline Resistance to earthquake & 0.644 & & & \\
\hline In a condiminum complex & 0.597 & & & \\
\hline With parking space & 0.588 & & & \\
\hline Factor 5: Open area related & & 5.327 & 0.60 & 2 \\
\hline With a garden & 0.643 & & & \\
\hline Play ground for children & 0.572 & & & \\
\hline Factor 6: Payment related & & 4.442 & 0.61 & 3 \\
\hline $\begin{array}{l}\text { Price that is to be paid in installment basis } \\
\text { to the construction Company }\end{array}$ & 0.776 & & & \\
\hline Reasonable price & 0.690 & & & \\
\hline Fit for mortgage & 0.680 & & & \\
\hline Factor 7: Modernity & & 4.113 & 0.64 & 2 \\
\hline Technology friendly & 0.760 & & & \\
\hline Newly built & 0.661 & & & \\
\hline Total variance explained & & 61.075 & & \\
\hline
\end{tabular}

Table 3_Three-Cluster Solution of Non-Hierarchical Cluster Analysis with Initial Seed Points from Hierarchical Results

\begin{tabular}{|l|r|r|r|r|r|r|r|r|}
\hline Cluster & F1 & F2 & F3 & F4 & F5 & F6 & F7 & N \\
\hline Final Cluster Centers & & & & & & & & \\
\hline Contenteds & 1.55 & 2.86 & 2.98 & 2.99 & 1.87 & 3.10 & 2.26 & 71 \\
\hline Dolce Vita & 2.66 & 3.18 & 2.33 & 3.29 & 3.18 & 2.84 & 2.76 & 51 \\
\hline City Dwellers & 2.39 & 3.42 & 3.48 & 3.53 & 2.89 & 3.54 & 3.16 & 61 \\
\hline F value & 76.0 & 26.1 & 55.7 & 21.5 & 94.3 & 22.8 & 29.170 & \\
\hline Significance & .000 & .000 & .000 & .000 & .000 & .000 & .000 & \\
\hline
\end{tabular}


(26.1\%) also consider investment as a reason of buying. These people are mostly single $(40 \%)$ or have families with two children (30\%). Thus, approximately $46 \%$ are young, at the early stages of their family life cycle, and $26.8 \%$ are over 45 . Compared to the other two clusters, they have lower income.

The dolce vitas consider luxury lifestyle $(\mu=2.66)$ and open area $(\mu=3.18)$ amenities the most when compared to the other two clusters. Thus, they want houses with gardens and luxury life style. They are also the ones who consider the payment factor $(\mu=2.84)$ the least among the clusters. Security $(\mu=3.29)$, house related $(\mu=3.18)$, and modernity $(\mu=2.76)$ amenities are considered in respective order, whereas location $(\mu=2.33)$ is not an important factor for them. They consider different purposes in the purchase of a house like: a second home as a country house or summer house $(31.4 \%)$ or investment (23.5). Approximately $60 \%$ of these people have families with two or more children. They $(70 \%)$ are middle aged or older, with $51 \%$ of them having high income.
City dwellers consciously consider many factors for choosing real estate. They are the ones who place the most importance on payment $(\mu=3.54)$, security $(\mu=3.53)$, location $(\mu=3.48)$, house related $(\mu=3.42)$, and modernity $(\mu=3.16)$ factors in respective order among the clusters. The least important factors for them are open area $(\mu=2.89)$, and luxury lifestyle $(\mu=2.39)$. These people want to live in the city center, in modern, good houses, with security and search for good payment conditions. Their main reason of buying is for living $(63.9 \%)$. They are evenly distributed in terms of family cycle and age. Their income level is medium $(39.3 \%)$ to low $(34.4 \%)$.

The sources of information were also examined regardless of the clusters to understand which sources were more frequently used by the consumers to search for real estate information. The results showed that the Internet $(60.4 \%)$, newspapers $(56.5 \%)$, friends/ relatives $4(50.7 \%)$, real estate agents $(32.9 \%)$, and real estate magazines $(18.4 \%)$ were used in respective order.

Table 4 Profile of the Three-Clusters (Cross-Tabs)

\begin{tabular}{|c|c|c|c|c|c|}
\hline & \multicolumn{5}{|c|}{ Profiling the Clusters } \\
\hline & & Clusters & City & Pearson & $\mathrm{p}$ \\
\hline Reason of Buying & Contenteds & Dolce Vita & Dwellers & Chi-Square & \\
\hline For living & $33(47.8 \%)$ & $13(25.5 \%)$ & $39(63.9 \%)$ & & \\
\hline Housing for other family members & $12(17.4 \%)$ & $10(19.6 \%)$ & $7(11.5 \%)$ & & \\
\hline As a second house & $6(8.7 \%)$ & $16(31.4 \%)$ & $7(11.5 \%)$ & & \\
\hline As an investment & $18(26.1 \%)$ & $12(23.5 \%)$ & $8(13.1 \%)$ & 23.448 & .001 \\
\hline \multicolumn{6}{|l|}{ Family Life Cycle } \\
\hline Single & $29(40.8 \%)$ & $7(13.7 \%)$ & $15(25 \%)$ & & \\
\hline Married w/out children & $6(8.5 \%)$ & $2(3.9 \%)$ & $6(10 \%)$ & & \\
\hline Single with children & $7(9.9 \%)$ & $1(2 \%)$ & $2(3.3 \%)$ & & \\
\hline Married with one child & $7(9.9 \%)$ & $10(19.6 \%)$ & $17(28.3 \%)$ & & \\
\hline Married with two children & $14(19.7 \%)$ & $18(35.3 \%)$ & $15(25 \%)$ & & \\
\hline Married with more than two children & $8(11.3 \%)$ & $13(25.5 \%)$ & $5(8.3 \%)$ & 28.832 & .001 \\
\hline \multicolumn{6}{|l|}{ Age } \\
\hline $19-23$ & $8(11.3 \%)$ & $1(2 \%)$ & $8(13.1 \%)$ & & \\
\hline $24-29$ & $25(35.2 \%)$ & $7(13.7 \%)$ & $11(18 \%)$ & & \\
\hline $30-35$ & $6(8.5 \%)$ & $7(13.7 \%)$ & $16(26.2 \%)$ & & \\
\hline $36-45$ & $13(18.3 \%)$ & $19(37.3 \%)$ & $18(29.5 \%)$ & & \\
\hline $45+$ & $19(26.8 \%)$ & $17(33.3 \%)$ & $8(13.1 \%)$ & 27.085 & .001 \\
\hline \multicolumn{6}{|l|}{ Income } \\
\hline Low & $30(42.3 \%)$ & $15(30.6 \%)$ & $21(34.4 \%)$ & & \\
\hline Medium & $24(33.8 \%)$ & $9(18.4 \%)$ & $24(39.3 \%)$ & & \\
\hline High & $17(23.9 \%)$ & $25(51 \%)$ & $16(26.2 \%)$ & 12.781 & .012 \\
\hline
\end{tabular}




\section{DISCUSSION AND CONCLUSION}

Real estate market in Turkey attracts the attention of domestic and foreign investors. The future projections of growth in the real estate market of İstanbul/Turkey shows the need for careful planning and marketing strategy building to get a share of the pie on the supply side. Just as it is true for the general running of every type of business in today's marketplace, profits will flow from finding of the right customers, designing the right projects for the satisfaction of customer needs and wants in the real estate market. Therefore, the most important thing is to be marketing oriented, customer focused, generate intelligence on the needs, wants, preferences, and behavior of different target customer groups, and act on that knowledge. This paper attempted this end.

The results showed that earthquake resistance is the most important amenity in general. Long term value of the house, reasonable prices, projects by a trustable construction company are also valued. The importance placed on earthquake resistance and preference of a trustable construction company are understandable considering the previous experiences of earthquakes, the financial and emotional damage caused by some untrustable construction companies; resulting in consumers sensitivity to reduce risk. Importance of price and long term value are not surprising as well since the literature already supported that the price of the property and its financial value have a strong influence in the evaluation of real estate alternatives (Anglin 1997).

These results have important implications for the success of any construction project in İstanbul. Earthquake resistance is a must that cannot be compromised for anything. Establishing brand name awareness and a trustable, credible, and a responsible corporate image is as critical, as well. The projects should also have reasonable payment conditions for the target customers, and finally communicate the idea of long term value increase of their real estate investment. It may be concluded that regardless of the segment the firm is targeting, the amenities disscussed above must be provided no matter what.

Although we have discussed what is deemed necessary for every construction project, still it is not possible to approach every customer in the same way. Segmentation and understanding the needs, wants, preferences, and behavior of the segments is important. The projects should be designed accordingly. This study identified three clusters or segments of customers, namely the contendeds, dolce vitas, and city dwellers.
The construction companies should take into consideration the differences in the needs and wants of these segments and design their projects according to these differences. The construction companies can apply either differentiated or concentrated marketing strategies depending on company objectives and resources. Moreover, competitors marketing strategies are also important to find out the unfullfilled gaps in the market to target to. Finally, they need to create a differentiated positioning based on these gaps and customer needs. This paper provides valuable information on which amenities are found most important by each segment; clarifying the customer needs for each segment.

The contendeds and city dwellers resemble each other on their choices. Payment is the most important amenity for both groups. Security, location, house-related amenities are also considered as important although in different order for both groups. The major difference lies in the fact that contenders are not strongly in search for any amenity except for affordability. This maybe because they act realistic and feel that as long as they can find an affordable house, they do not have much choice. These people are at the early stages of their lives or people in their middle ages with low income. The city dwellers are more demanding and searching for more amenities, at the same time not giving up the price. They prefer to live in the city, with a better income level than the contendeds. Finally, there is another segment, the dolce vitas, who are in search of a better, luxurious life outside the city, in big houses with gardens. These people are affluent and older in age. These findings are compatible with the previous research findings that upper income customers prefer housing outside the city center in suburban locations, while low income families reside in the cities, close to work. (Elder and Zumpano 1991). The projects should be built taking into consideration these three segments and their requirements.

Even though creating the right project is important, what is equally important is to create the overall marketing strategy in these projects: starting with segmentation, target marketing, choosing the right target market, and finding a distinctive position to occupy in the target customers' minds. For contendeds the differentiaition lies in price, and affordability; however for city dwellers it lies in creating the delicate equilibrium between price and the desired amenities. For dolce vitas, luxury and being outside the city is the key.

Based on these differences, the image of the construction company and the project, the project amenities, geographical position of the project, prices 
and payment conditions should be differentiated and communicated to the target consumers. For the integrated communication strategy, the results of this study show that the Internet is the most commonly prefered source of information, followed by newspapers, and friends/ relatives. Given the increased use of the Internet in the Information Age, this result is not surprising. Interesting finding is that real estate agents are not very much prefered even though national and international real estate agents are openning their offices at an increasing rate all over the country (Cingi 2007). The implication for real estate companies is that they should make use of the Internet, print media, and customer references as a communications strategy for their real estate projects.

\section{REFERENCES}

Anglin, P. M. (1997), Determinants of Buyer Search in a Housing Market, Real Estate Economics, 25 (4), pp.567-589.

Baryla, E. A. and L. V. Zumpano (1995), Buyer Search Duration in the Residential Real Estate Market: The Role of the Real Estate Agent, The Journal of Real Estate Research, 10 (1), pp.1-13.

Bayraktar, E. (06.12.2007), "Türkiye'de Konut İhtiyacının Niteliği/ The Quality of the Real Estate Need in Turkey," Emlak ve Mortagage Eki (Real Estate and Mortgage Insert), Sabah Gazetesi.

Benjamin, J.D., G. D. Judd, and G.S. Sirmans (2000), Real Estate Brokerage and the Housing Market: An Annotated Bibliography, Journal of Real Estate Research, 20 (1/2), pp.217-277.

Cingi, S. (2007), Gayrimenkul Devleri, Mahalle Emlakçısını Kapma Savaşına Girdi-The Giants of Real Estate Fight to Win the Corner Real Estate Retailers, Referans Gazetesi, retrieved from http://www.kobifinans.com.tr/tr/icerik.php?Article= $17006 \&$ Where $=$ sektor $\&$ Category $=011703$.

Day, e. And H. Nourse (1991), Client Selection of a Residential Real Estate Agent, Journal of Professional Services Marketing, 6 (2), pp.81-95.

Elder, H.W., Zumpano, V. (1991), Tenure choice, housing demand and residential location, Journal of Real Estate Research, Vol. 6 No.3, pp.341-56.

Emerging Trends in Europe 2007, retrieved from http://www.pwc.com/extweb/ncevents.nsf, on 10.05.2008.

Ford, J.S., R.C. Rutherford, ad A. Yavas (2005), The Effects of the Internet on Marketing Residential Real Estate, Journal of Housing Economics, 14, pp.92-108.

İçli, G.E. (2008), Konut Pazarlamas1/ Real Estate Marketing, Beta (İstanbul).

Işıkören, H. (07.02.2008), Emlak sektöründen 2008'e Bakış/ A Look into 2008 from the Real Estate Sector, Milliyet Emlak, retrieved from

http://blog.milliyet.com.tr/Blog.aspx?BlogNo=90752.

Johnson, D.D. and S. W. Hamilton (1996), Housing Market Conditions, Listing Choice and MLS Market Share, Real Estate Economics, 26 (2), pp.275-307.

Konutta fiyatlar TOKİ seviyesinde/ The house prices are at TOKİ levels (15.12.2008), www.emlakkulisi.com.

Kotler, P. and G.Armstrong (2008), Principles of 